\title{
The effect of thermal treatment on the properties of SLM samples with a bionic design
}

\author{
Vladimir Dub ${ }^{1, *}$, Pavel Medvedev ${ }^{1}$, Konstantin Kudrin ${ }^{1}$, Aliy Delov ${ }^{2}$, Stepan Stepanov ${ }^{3}$, \\ Dmitriy Sviatoslavov ${ }^{1}$, and Michael Sinelnikov ${ }^{1}$ \\ ${ }^{1}$ I.M. Sechenov First Moscow State Medical University, 119146 Moscow, Russia \\ ${ }^{2} \mathrm{AO}$ «Nauka i innovacii», 115035 Moscow, Russia \\ ${ }^{3}$ Ural Federal University named after the first president of Russia B.N. Yeltsin, 620002 Ekaterinburg, \\ Russia
}

\begin{abstract}
This article shows the possibility of additive technology applied to medical implants. It's shown the difference of physical properties such as elastic module of bones, implants made of traditional technology and implants made of additive technology. Porous structure has been chosen for future implants through designing its and further calculation of its mechanical properties using software such as SolidWorks, Logos and Ansys. To confirm the right choice of design of structure we manufactured samples with using Rosatom 3D printer, made heat treatment and tested them.
\end{abstract}

\section{Introduction}

The use of titanium (GOST 5832-2) in medicine is gaining popularity, especially in the field of personalized prosthetics. Due to highly favorable qualities, such as inertness, hypoallergenic, biocompatible and firm structural characteristics, the use of titanium is permissible in a wide variety of clinical cases. Despite advantageous characteristics of the prosthetic material, traditionally prepared titanium implants do not provide necessary physiological compatibility and biointegration. These important properties can be achieved through personalized implant development, individual weight and size modification, physiological and anatomical osteointegration.

Recent studies have shown active integration of additive technologies in biomedical engineering. Also, this kind of manufacturing method of implants is energetically more effective than traditional method of metal machining. The advances in this field have allowed for the creation of complex geometrical titanium structures for implantation. Our study is based on the ability to design a structure with operating characteristics similar to osseous tissue. The process of modeling of these structures requires precise computerized design and extremely accurate production. An often-overseen variable in the production process of modern bionic structures is thermal treatment. This is one of the key steps in the preparation of high-quality personalized titanium biocompatible implants.

\footnotetext{
*Corresponding author: dubv@me.com
} 


\section{Implant structural design}

Titanium alloy implants are the most promising structures in bionic engineering. Comparison of physicochemical and structural properties of osseous tissue and VT1-00 titanium implant show excess mechanical characteristics of the later, which cause difficulties in biological osteointegration.

Table 1. Comparison of properties of bones and VT1-00

\begin{tabular}{|c|c|c|c|}
\hline & $\begin{array}{c}\text { Cast implant } \\
(\text { VT1-00) }\end{array}$ & Cortical bone & Cancellous bone \\
\hline Mass & $4,5 \mathrm{~g}$ & $1,5 \mathrm{~g}$ & $0,2 \mathrm{~g}$ \\
\hline Elastic modulus & $110 \mathrm{GPa}$ & $10 \mathrm{GPa}$ & $1-5 \mathrm{GPa}$ \\
\hline Tensile strength & $200 \mathrm{MPa}$ & $50 \mathrm{MPa}$ & $5-10 \mathrm{MPa}$ \\
\hline
\end{tabular}

Proper osteointegration requires the bioengineered implant to have a porous structure with microgeometrical configuration similar to that of osseous trabecular tissue. This requires the implant to have pore size varying from $100-1000 \mu \mathrm{m}$, with over $70 \%$ porous consistency medium, as well as rough material surface quality [1-7]. Based on current understanding of material requirements for biointegration, we have developed a bionic structure with necessary functional and physical-structural characteristics for proper osteoinegration in vitro.

Given implant specifications. The developed titanium alloy 3D-printed bionic implant has an open cell pore size of $600 \mu \mathrm{m}$. This network of spaces is divided by titanium trabeculae $(300 \mu \mathrm{m}$ in diameter), similar to that of a cancellous bone. The open cells between artificial titanium trabeculae form tetragonal pores. This design provides the implantable material with significant advantages, including a highly stable and developed open cellular structure for complex osteointegration with trabecular osseous tissue. The high porous consistency (over $70 \%$ ) and low elasticity coefficient (1.5 GPa - based on ANSYS analysis) with high porous consistency and biocompatible characteristics of titanium make this implantable material highly effective and suitable for bionic design (Table 1).

\section{Biointegratable titanium implant production}

The proposed titanium implant structure required a specially designed production algorithm. In order to acquire the desired implant characteristics, an experimental production program was developed, in which implant samples were prepared and later functionally tested. Implant preparation included selective laser melting (SLM) with subsequent annealing under different exposition protocols.

Heat treatment protocol. Selection of necessary heat treatment conditions was based on 6 different annealing protocols, which were carried out on different titanium implant samples after selective laser melting. 6 ductility samples with a $6 \mathrm{~mm}$ working area (GOST 1497) and 6 cubic samples with a $10 \mathrm{~mm}$ edge and a porous structure (ISO 13314) with previously listed specifications (see "Given implant specifications"). Samples were printed on a Russian-made 3D-printer for layered printing via selective laser melting (SLM) of metallic powdered materials (MeltMaster3D developed by Rosatom). Titanium VT1-00 metallic powder was used (Table 2). 
Table 2. Chemical composition.

\begin{tabular}{|c|c|c|c|c|c|c|c|c|}
\hline Alloy & $\mathrm{Ti}$ & $\mathrm{O}$ & $\mathrm{N}$ & $\mathrm{H}$ & $\mathrm{Fe}$ & $\mathrm{Si}$ & $\mathrm{C}$ & $\begin{array}{c}\text { Other } \\
\text { materials }\end{array}$ \\
\hline VT1-00 & base & 0,11 & 0,02 & 0,001 & 0,02 & - & 0,02 & - \\
\hline $\begin{array}{c}\text { GOST R ISO } \\
5832-2 \\
\text { (Grade 1 ELI) }\end{array}$ & base & 0,1 & 0,012 & 0,0125 & 0,1 & - & 0,03 & - \\
\hline
\end{tabular}

As seen in Table 2, the titanium alloy chosen for the study has a high quality, similar to that of high purity Grade 1 ELI titanium. Requirements for mechanical properties in comparison with the properties according to GOST are given below (Table 3).

Table 3. Mechanical properties of bone and Titan.

\begin{tabular}{|c|c|c|c|c|c|c|}
\hline Model & Treatment & $\begin{array}{c}\sigma_{0,2}, \mathrm{MPa} \\
\text { (Flow } \\
\text { stress) }\end{array}$ & $\begin{array}{c}\sigma_{\mathrm{B}}, \mathrm{MPa} \\
\text { (Ultimate } \\
\text { tensile } \\
\text { strength) }\end{array}$ & $\begin{array}{c}\delta, \% \\
\text { (Residual } \\
\text { elongation) }\end{array}$ & $\begin{array}{c}\psi, \% \\
\text { (Relative } \\
\text { narrowing) }\end{array}$ & $\begin{array}{c}\mathrm{E}, \mathrm{GPa} \\
\text { (Young's } \\
\text { modulus) }\end{array}$ \\
\hline Requirements & $\begin{array}{c}\text { not } \\
\text { defined }\end{array}$ & $210 \ldots 700$ & $150 \ldots 530$ & $12 \ldots 40$ & $20-30$ & $1-7$ \\
\hline $\begin{array}{c}\text { Trabecular bone } \\
\text { structure [8] }\end{array}$ & none & 200 & 140 & 30 & - & 110 \\
\hline $\begin{array}{c}\text { GOST R ISO } \\
5832-2 \\
\text { (Grade 1 Eli) }\end{array}$ & annealed & $5-15$ & & & 110 \\
\hline $\begin{array}{c}\text { GOST R ISO } \\
5832-2 \\
\text { (Grade 4) }\end{array}$ & annealed & 550 & 483 & 15 & - & \\
\hline
\end{tabular}

Selection of heat treatment conditions of unalloyed titanium after SLM. Evaluated temperature of heat treatment ranged between $625-725^{\circ} \mathrm{C}$. This temperature range was chosen based on experience with undoped titanium and literature data. It should be noted that the increase in the annealing temperature was accompanied by a drop in strength for the entire investigated interval. An increase in the annealing temperature from $675^{\circ} \mathrm{C}$ to $725^{\circ} \mathrm{C}$ does not lead to an increase in plasticity. Based on our findings, the recommended heat treatment consists of 1 hour sample exposition at $675^{\circ} \mathrm{C}$. This heat treatment allows the titanium implant sample to achieve required physical and mechanical properties and correspond to wrought titanium (GOST R ISO 5832-2, Grade 4).

Mechanical properties and annealing of porous implant samples. Annealing of the porous titanium VT1-00 implant samples after SLM was conducted similarly to that of unalloyed titanium samples. Mechanical qualities were evaluated via the ISO 13314 method for porous and cellular metals, the acquired results are presented in Table 4 and Figure 1, Figure 2. The test system ISO 13314 for mechanical, ductile, compression testing includes the following parameters: $\sigma \mathrm{pl}$ - mean plateau stress at strain intervals between $20 \%$ and $30 \%$, omax - first maximum compressive strength during transition from elastic to plastic deformation on a stress-strain diagram for tension. In our opinion, the main characteristic of porous sample stability should be chosen from the minimum of the listed. omax - can only be analyzed for 
samples with $725^{\circ} \mathrm{C}$ annealing longways, annealing $725^{\circ} \mathrm{C}$ across, annealing $675^{\circ} \mathrm{C}$ across, and in this case the result is higher than the conditional yield strength. $\sigma \mathrm{pl}$ for porous titanium VT1-00 samples was consistently $>2$ times greater than $\sigma 0.2$. Therefore $\sigma 0.2$ was used as a sample strength characteristic. The elasticity coefficient for all samples varied from $1.5 \pm 0.5$ $\mathrm{GPa}$. The authors conclude that the plasticity characteristic did not depend on annealing protocol, but the sample strength properties consequently decreased with the rise of annealing temperature.

Table 4. Physical and mechanical properties of samples depending on heat treatment conditions.

\begin{tabular}{|c|c|c|c|c|c|c|}
\hline $\begin{array}{c}\text { Sample } \\
\text { preparation }\end{array}$ & Direction & $\sigma_{0,2}, \mathrm{MPa}$ & $\sigma_{\mathrm{B}}, \mathrm{MPa}$ & $\sigma_{\text {max }, \mathrm{MPa}}$ & $\mathrm{E}, \mathrm{GPa}$ & eple, \% \\
\hline \multirow{2}{*}{$\begin{array}{c}\text { SLM (without } \\
\text { annealing) }\end{array}$} & longways & 66 & 133 & - & 1,7 & 44 \\
\cline { 2 - 7 } & across & 60 & 131 & - & 1,9 & 43 \\
\hline \multirow{2}{*}{$\begin{array}{c}\text { Annealing at } \\
625^{\circ} \mathrm{C}\end{array}$} & longways & 55 & 114 & - & 1,6 & 44 \\
\cline { 2 - 7 } & across & 57 & 119 & - & 1,6 & 43 \\
\hline \multirow{2}{*}{$\begin{array}{c}\text { Annealing at } \\
675^{\circ} \mathrm{C}\end{array}$} & longways & 47 & 101 & - & 1,4 & 44 \\
\cline { 2 - 7 } & across & 30 & 81 & 40 & 1,7 & 44 \\
\hline \multirow{2}{*}{$\begin{array}{c}\text { Annealing at } \\
725^{\circ} \mathrm{C}\end{array}$} & longways & 38 & 82 & 43 & 1,1 & 45 \\
\cline { 2 - 7 } & across & 41 & 97 & 49 & 1,1 & 44 \\
\hline
\end{tabular}

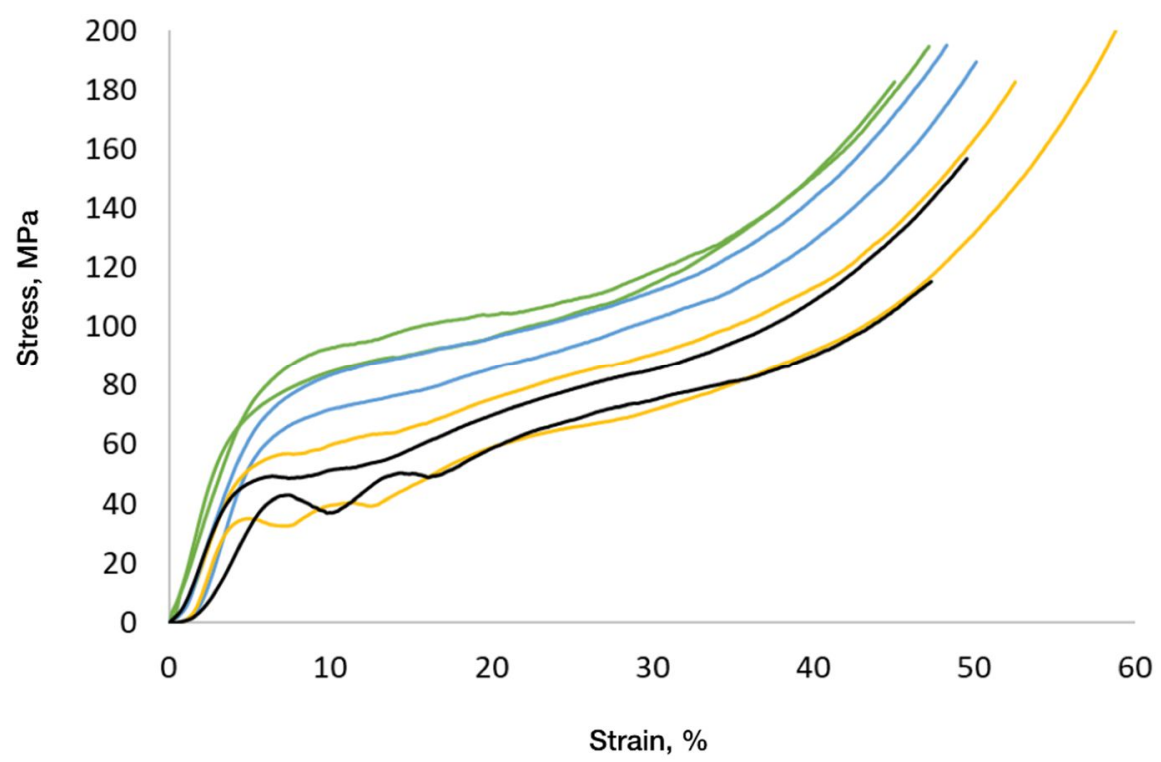

Fig. 1. Stress-strain diagram to determine the characteristic values from compression testing of porous samples under different preparation protocol (after SLM only - green; annealing at $625^{\circ} \mathrm{C}$ blue; annealing at $675^{\circ} \mathrm{C}$ - yellow, annealing at $725^{\circ} \mathrm{C}$ - black). 


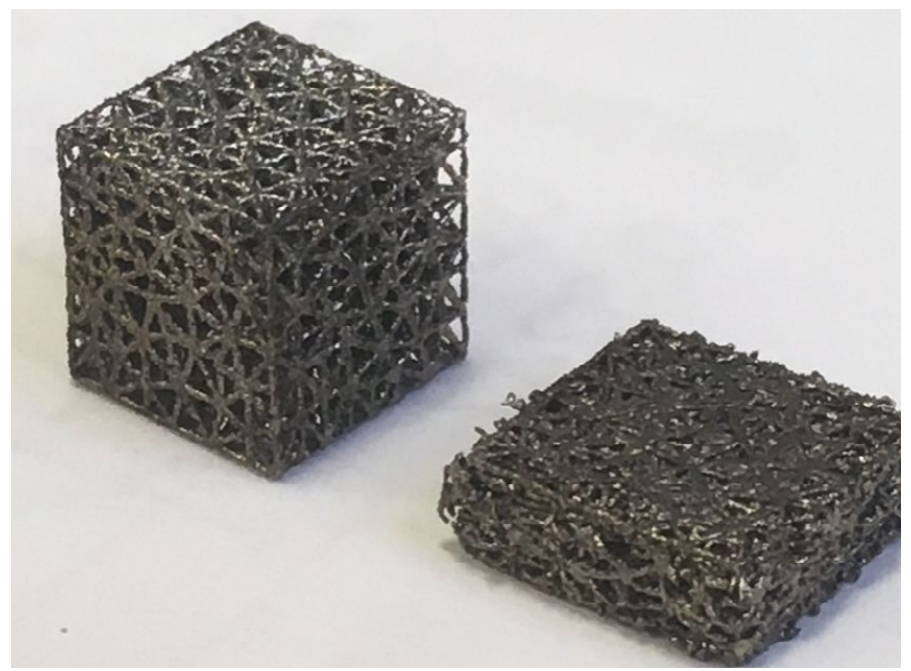

Fig. 2. Photo of porous samples before and after ISO 13314 testing.

Porous structures that underwent only SLM showed a tendency to deviate from original cubical form, due to weakness of unannealed titanium structural component and occurrence of local thermal stresses.

\section{Conclusion}

Personalized titanium VT1-00 implants in this study successfully adapted necessary characteristics for proper osteointegration with tuberous osseous tissue. The method of choice for bionic biointegratable implant production is SLM with consequent annealing at $675^{\circ} \mathrm{C}$ for 1 hour. Annealing should be performed until the implant is separated from the plate in order to exclude deformation of the implant.

\section{References}

1. D. F. Williams, F. Roug, Implants in surgery (Medicina, Moscow,1978)

2. L. Linkov, Without teeth prosthetics (Kometa, Saint Petersburg, 1993)

3. V. V. Savich, M. G. Kiselev, A. I. Voronovich, Modern surgical implant materials. 2nd Edition. (OOO "Doctor Dizayn”, Minsk, 2004)

4. A. D. Levi, W. G. Choi, P. J. Keller, J. E. Heiserman, V. K. Sonntag, C. A. Dickman, Spine, 23, 11, 1245 (1998)

5. O. V. Mikhailov, L. N. Tkachenko, M. B. Shtern, V. A. Dubok, Powder Metallurgy and Metal Ceramics, 1-2, 10 (2003)

6. A.A. Smetkin, A.N. Yarmonov, S.G. Konyukhova, Proceedings of the 5th Intern. Scien. Conf. "New materials and technologies: Powder metallurgy, composite materials, protective coatings" Minsk, 30, (2002)

7. V.I. Kalita, V.A. Paramonov, Physics and Chemistry, 6, 37 (2002)

8. T. M. Keaveny, E. F. Morgan, G. L. Niebur, O.C. Yeh, Annual review of biomedical engineering, 3(1), 307 (2001) 